\title{
An Empirical Study on the Entrepreneurial Environment of College Students of Science and Technology Demand Based on Life Cycle
}

\author{
Cheng $\mathrm{Li}^{1}$, Xin Chen ${ }^{1} \&$ Yang Zhang ${ }^{1}$ \\ ${ }^{1}$ Shanghai University of Engineering Science, Shanghai, China \\ Correspondence: Cheng Li, School of Air Transportation / Flying, Shanghai University of Engineering Science, \\ China. Tel: 86-182-2155-2006. E-mail: Lcheng8066@126.com \\ Received: May 13, 2015 \\ Accepted: July 9, 2015 \\ Online Published: July 21, 2015 \\ doi:10.5430/bmr.v4n3p8 \\ URL: http://dx.doi.org/10.5430/bmr.v4n3p8
}

\begin{abstract}
This paper reviews the domestic and foreign scholars' studies of the factors on the entrepreneurship environment, put forward 7 first-level indexes and 26 second-level indexes on entrepreneurship environmental. Based on the model of the study of entrepreneurship environment and life cycle, we do investigate 21 college students entrepreneurial companies in Songjiang and do assess college students' scientific innovation environment. Point out that at different stages of the life cycle this special business groups have different entrepreneurial environment characteristics. This would provide the basis for entrepreneurial success, and help the local government to optimize the policy and measures, to pin-point and to improve the college students of science and technology entrepreneurship environment.
\end{abstract}

Keywords: College students' entrepreneurship, Science and technology entrepreneurship environment, Life cycle

\section{Introduction}

Since 2008, influenced by the global economic crisis, with the expansion of global economic recession, the economic our country is faced with enormous challenges. University students' employment pressure is becoming bigger, the increasingly severe employment situation, also makes college students' employment problem more and more prominent since 2003. College students are national valuable human resources, and how to fully develop the functions of university education to help the economic take off, this is the realization of building an innovation oriented country strategy target. College students' entrepreneurship becomes a trend. College students' entrepreneurship for employment way gradually becomes a new model of employment. University technology business has significant leading effect on employment.

Employment, not only in relation to a person's livelihood, but also it is related to one's dignity. More and more people realize that, under the condition of market economy, China as the world's largest developing country, the fundamental way of building a harmonious society is to full employment, how to make the students who accepted more than 10 years education be able to rely on themselves to create the value in the society when they out of the gate has become a hot issue in the social from all walks of life. Meanwhile the successful development of a part of the private high-tech enterprises, however, the majority of private technology enterprises experienced a short booming and then rapidly decline, even disappear. In the GEM (2006) China's report pointed out that in 2005, China's science and technology start-ups closed rate is $5.18 \%$, is 1.9 times of the average level of GEM; since china's reform and opening up, a large number of private science and technology enterprises had set up but less than $30 \%$ have survived today.

Again take the participator as an example supported by the fund of science and technology business enterprise in Songjiang. Since 2007 the university technology business division foundation was set up to June 30, 2009, a total of 2.28 million Yuan of venture fund have been appropriated to 21 students to help them to set up their own business enterprise; Among them, 13 business enterprise on the science and technology, accounting for $62 \%$ of the 21 enterprises, planned to allocate 1.57 million accounting for $69 \%$ of total plans to allocate quotas; At present 3 enterprises has applied for dissolution or has disbanded, and they are scientific and technological enterprises, accounted for $23 \%$ of 13 science and technology enterprises. Less than two years, $23 \%$ of the science and technology enterprise elimination once again warned us: What is the reason for the high rate of elimination of enterprises, it will bring what effects on college students' science and technology enterprise, whether have rules to follow and how to change this kind of phenomenon? 
Enterprise life cycle theory reveals that enterprise is as a person, and also has its own life cycle, also has its own growth and development rules. Different stages of different enterprise have different characteristics, and the adaptation and needs of the internal and external environment are not the same. According to the angle of the enterprise life cycle, this paper will explore students' science and technology entrepreneurship environment. Through the analysis and study on entrepreneurial environment in different stages of the life cycle, this paper is trying to find the rules in effect, to create more favorable entrepreneurship environment, effectively to improve the success rate of entrepreneurship of university students in science and technology, to provide a scientific basis, to be the real implementation of Central Committee and State Council putting forward the "entrepreneurial drive employment", and to make a valuable exploration to solve the employment problem of College students. The enterprise life cycle theory is an important theory of the research on enterprise management. This theory regards the development of enterprises as a simulation of the life cycle of the organism, from birth to growth, maturation and death four stages. Researchers generally believe that, with the development of the enterprise life cycle stage, enterprises only continue to change management ideas and methods accordingly, and then enterprises could be in an invincible position.

\section{The construction of university technology entrepreneurship environment index system}

\subsection{Review of research on entrepreneurship environment}

Starting from the essence of entrepreneurial environment, entrepreneurial environment poses several environmental elements content. Table 1 shows the numerous domestic and foreign scholars on the entrepreneurial environment elements are studied.

Table 1. Elements of entrepreneurship environment

\begin{tabular}{|c|c|c|}
\hline Researchers & Time & The constituent elements of entrepreneurship environment \\
\hline Porter & 1980 & $\begin{array}{l}\text { Barriers to entry, The state of competition of dcurrent competitors, Alternatives to } \\
\text { threats,Buyers bargaining ability,Supplier bargaining ability }\end{array}$ \\
\hline Gartner & 1995 & $\begin{array}{l}\text { All the above factors, The high proportion of population in recent } \\
\text { immigrants,Large-scale urban area,Strong industrial base,The availability of } \\
\text { financial resources,Industrial specialization degree }\end{array}$ \\
\hline Gnyawall Fogel & 1994 & $\begin{array}{l}\text { Innovation service environment, The policy environment,Financing } \\
\text { environment,Cultural environment }\end{array}$ \\
\hline \multirow[t]{2}{*}{ GEM } & 1999 & $\begin{array}{l}\text { The financial support, The government's support, The government project } \\
\text { support,Education and training,The research and development to transfer }\end{array}$ \\
\hline & & $\begin{array}{l}\text { Business and professional infrastructure,Barriers to entry, The physical } \\
\text { infrastructure,Cultural and social norms }\end{array}$ \\
\hline Annalee,Saxenian & 2000 & $\begin{array}{l}\text { On the basis of the regional network of industrial system,Dense social } \\
\text { network,Open the talent market,Region's social and cultural atmosphere }\end{array}$ \\
\hline Deborah,Markley & 2002 & Social atmosphere,Public infrastructure, The government's support \\
\hline Joerg Baten & 2003 & $\begin{array}{l}\text { Wages,Personal wealth,policy,Industry clustering degree,Regional specialization } \\
\text { degree }\end{array}$ \\
\hline Renhong Zhu & 2004 & $\begin{array}{l}\text { General environment (social, political, economic, cultural, system, technology, } \\
\text { infrastructure conditions),Entrepreneurship environment (financing environment, } \\
\text { technical environment, government support, cultural and social based handouts and } \\
\text { other professional business environment) }\end{array}$ \\
\hline Henri,Grundsten & 2004 & The perceptual environmental elements, Rational environmental elements \\
\hline Yuanyuan Guo & 2006 & $\begin{array}{l}\text { Environmental support, Economic base, Cultural support, Scientific support, } \\
\text { Service support }\end{array}$ \\
\hline Li Cai & 2007 & Policies and regulations environment, technology environment, market environment \\
\hline Yinan $\mathrm{Su}$ & 2009 & $\begin{array}{l}\text { Economic environment, Policy environment, Education and training environment, } \\
\text { Social and cultural environment, Financing environment }\end{array}$ \\
\hline Xiue Zhang & 2010 & Resources and environment, the environment of embedded elements \\
\hline
\end{tabular}


Table 1 reflects both at home and abroad the elements of entrepreneurial environment has a variety of categories, but on the whole, the entrepreneurial environment subject is structured by political (government policy), economic, financing, social and cultural macro environment and industry environment.

\subsection{Construction of university technology entrepreneurship environment index system}

\subsubsection{Principle}

\section{(1) Scientific}

Selecting any index would have its own theoretical basis. Based on the reference of foreign index of GEM, combined with the characteristics and forms of university technology business, the basic situation of business life cycle, this paper has chosen index system construction, In line with the characteristics of university technology business environment, so the index selection absolutely has some scientific effect.

(2) Measurable

Foreign index system is very comprehensive, and is a very good research framework. It is worth learning from domestic scholars. But some indicators are poor, and can not accurately evaluate the entrepreneurial environment. Therefore, in this paper, we consider the index of the measurement, the selection of indicators generally can be obtained from the statistical yearbook.

\section{(3) Comparable}

Any college students of science and technology index of entrepreneurship environment do not exist independently, and there are connections between each other. The purpose of this study is to compare entrepreneurship environments, to provide advice as the references for college students of science and technology business and to provide theoretical basis for government to optimize the entrepreneurial environment.

\section{(4) Hierarchical}

The entrepreneurship environment is a complex system. It can be divided into several subsystems, and because the index system is mainly to provide information for decision making at all levels of government, and the government at all levels of control and management can solve the business problems. Therefore, the advantages and disadvantages of the entrepreneurship environment should be measured at different levels, and it can be operated with the best possible.

(5) Comprehensive

Various factors can reflect the influence on the entrepreneurial activity, but if the indicators cannot be quantified or the data is difficult to be obtained, the index should not be included in the index system.

\subsubsection{Construction of index system of entrepreneurial environment}

Student entrepreneurs have the higher educational level, strong innovation consciousness, but they are insufficient, lack of market competition consciousness, poor risk tolerance, poor entrepreneurial stability, relevantly lack of funds and policy support. Also science and technology enterprises have some characteristics, for example, high investment, high risk, high income, high-tech and high-growth. Therefore, the research on college students' science and technology entrepreneurship environment is different comparing with the general business environment, science and technology entrepreneurship of the college students must be based on such elements as the government's policy, economic, culture of a certain society and also need pay more attention to talents, market, the financing factors, etc. Specific descriptions are as follows (as shown in Table 2):

\section{(1) Location environment}

A good entrepreneurship environment must have the perfect infrastructure. Traffic facilities and natural resources are important. Improving communication facilities is conducive to quickly grasp the market information, adapt to market changes. All including convenient traffic are the ensurances of success. Therefore, a good business environment must have perfect transportation, abundant natural resources. This article selects two indicators which are the convenient traffic and abundant natural resources.

(2) Economic environment

Any business is in support of a certain economic basis, without good economic environment of entrepreneurial activity the business must fail. The economic environment of a country refers to the economic development level of the economic system and the economic development level and the economic trend of the future, etc. In this paper, the economic environment is mainly the economic development of the city, mainly refers to three industrial structures, 
GDP, above scale industrial added value and total imports and exports, etc.

(3) Policy environment

In the market economy, the role of the government is not to play the game, but to make the judges, to determine the rules of the game and the implementation of economic policies. The political environment directly influences the enthusiasm of people, and it is the premise and foundation of the business environment, but also the catalyst for the occurrence of entrepreneurial activity. It can attract entrepreneurial talent variable factors through a place on their own efforts to create. The promotion of this index has a very important role in the optimization of the entrepreneurial environment. Combined with the actual situation, the evaluation index of political has three factors which are determined for Administrative office efficiency, the Entrepreneur Award (preferential) policy and entrepreneurship policy consummation degree.

Table 2. Index system of entrepreneurship environment

\begin{tabular}{|c|c|c|c|}
\hline $\begin{array}{l}\text { first-level } \\
\text { indexes }\end{array}$ & second-level indexes & $\begin{array}{l}\text { first-level } \\
\text { indexes }\end{array}$ & second-level indexes \\
\hline \multirow{2}{*}{$\begin{array}{c}\text { Location } \\
\text { environment }\end{array}$} & natural resources & \multirow{3}{*}{$\begin{array}{l}\text { Marketing } \\
\text { environment }\end{array}$} & market size \\
\hline & traffic & & market competition rate \\
\hline \multirow{4}{*}{$\begin{array}{l}\text { Economic } \\
\text { environment }\end{array}$} & three industrial structure & & market concentration rate \\
\hline & GDP & \multirow{6}{*}{$\begin{array}{l}\text { Science and } \\
\text { technology } \\
\text { environment }\end{array}$} & number of universities \\
\hline & above scale industrial added value & & $\mathrm{R} \& \mathrm{D}$ funds \\
\hline & total imports and exports & & conversion rate \\
\hline \multirow{3}{*}{$\begin{array}{c}\text { Policy } \\
\text { environment }\end{array}$} & Administrative office efficiency & & operating status \\
\hline & Entrepreneur Award policy & & concentration rate \\
\hline & policy consummation degree & & degree of industrial linkage \\
\hline \multirow{4}{*}{$\begin{array}{c}\text { Financing } \\
\text { environment }\end{array}$} & degree of diversification of investment & \multirow{4}{*}{$\begin{array}{c}\text { Talent } \\
\text { environment }\end{array}$} & talent incentive measures \\
\hline & policy orientation & & degree of perfection of the talent \\
\hline & risk investment development & & flow efficiency \\
\hline & guarantee system & & $\begin{array}{l}\text { Scale of the professional and } \\
\text { technical personnel }\end{array}$ \\
\hline
\end{tabular}

(4) Financing environment

For the new enterprise, GEM hold that the source of the capital mainly has three ways: private equity capital, capital financing, second-board market financing. In this article, we regard the degree of diversification of investment, the policy orientation of the college students' science and technology business enterprise, risk investment development status and the guarantee system construction as secondary indicators.

(5) Marketing environment

Market environment analysis includes demand analysis. Every company has to consider their own products can be accepted by the customer. It also means that the customer whether have such needs, and also need to know how much demand. A company can sell out to make profit in high demand situation.

(6) Science and technology environment

Science and technology is the first productivity. The technological development of the related industries also has a certain degree of influence on the occurrence of entrepreneurial activity in related fields. Here, we mainly analyse technology environment influence on high-tech entrepreneurial activity, because the entrepreneurial process also need a good technical environment to support. We select number of universities and research institutes, R\&D funds, the conversion rate of scientific and technological achievements, the operating status of the technology market, the concentration of technology industry, the degree of industrial linkage as secondary indexes.

(7) Talent environment

Talent environment is mainly to meet the needs of the people and the labor force. It includes several aspects, such as the talent incentive measures, the degree of perfection of the talent market, talent flow efficiency and the scale of the 
professional.

\section{Model construction and empirical study}

\subsection{Research framework}

(1) Modelling and parameter description

Science and technology enterprises in different stages of the life cycle have different characteristics. According to Table 2, seven environmental factors constitute the content of college Students' scientific and technological entrepreneurship environment. Because in different life cycle stages, university technology enterprises face the different venture, so in theory, in different life cycle stages, university technology enterprise need different technology entrepreneurial environment to support. In view of this, this paper proposes environmental research model of entrepreneurship based on life cycle:

$$
Y=a X+b Y+c Z+d
$$

$\mathrm{X}$ : university technology business environment variables;

Y: university technology business life cycle (seed stage, venture creation period, development period, the mature period), Combined with the actual situation of College Students' scientific and technological entrepreneurship development in songjiang, at present most of the scientific and technological enterprises have not yet entered the mature stage. Therefore, in our study, research focus in three stages: seed stage, the creation and evelopment period.

$Z$ : shows that the technological entrepreneurship of college students is influenced by the entrepreneurial environment and the life cycle.

a: environment factor, determined by the overall status of the science and technology entrepreneurial environment;

b: coefficient of technology entrepreneurs' life cycle;

c: coefficient of business life cycle and business environment under the combined actions;

d: auxiliary constant.

(2) Characteristics and innovation of the model

In different life cycle stages, college students' scientific and technological entrepreneurship needs different entrepreneurial environment, and the same business environment plays different roles in different life cycle stages.

Positive correlation exists among college students' entrepreneurship, entrepreneurial environment and entrepreneurial life cycle. On the premise of keeping the internal factors, the success rate of college students' success is improved by the specific technology and the environment.

This special group of entrepreneurs need different environment in different life cycle stage, which is the first analysis.This paper reveals the effective macro-control will be a strong impetus to the scientific and technological entrepreneurship of College students.

\subsection{Empirical study}

(1) Environmental factor design and selection

From the above we can know, College students innovation environment consists of seven elements. In different life cycle stages, enterprises are facing policy, marketing, financing and talent environment. But in a short time location environment factors and economic environment factors will not change along with the policy adjustment. Thus, in the empirical stage, this paper just selects policy, financing, marketing, science and technology and talent these five elements. Because in different stages of life cycle, these five kinds of environment factors have more stronger influence on college students innovation enterprises, and in the process of entrepreneurship, these five environmental factors have directly relationship to various risks that college students innovation enterprises will facing.

\section{(2) Sample design and selection}

Based on the theoretical model design above, we investigated college students' scientific and technological enterprises in different stages of the life cycle, used the methods combine with questionnaire survey, interviewed and telephoned interviews, we acknowledged about 21 college students' scientific and technological enterprises. The basic situation of 21 college students' scientific and technological enterprises is shown in Table 3:

(3) Study on the relationship between college students' entrepreneurial environment and life cycle

In order to determine the university technology business enterprise in the different stages of business life cycle 
whether there are different needs or not, this paper uses discriminant analysis method to analysis the 21 enterprises participated in the survey.

Table 3. Basic situation of students in scientific and technological enterprises

\begin{tabular}{|c|c|c|}
\hline Years of Enterprises set up & Number of samples & life cycle \\
\hline preparatory period & five & seed stage \\
\hline within 1 years & six & creation stage \\
\hline $1-3$ years & five & creation stage \\
\hline $3-5$ years & five & development stage \\
\hline
\end{tabular}

In the 20 second-level indexes, because "flow efficiency"and "scale of Professional and technical personnel" do not have significant characteristics, so they are eliminated in the process of operation, this has reflected that the 2 elements of the talent environment have no significant affections to the 21 enterprises in the different life cycle stages. The remaining 18 variables are composed of 2 canonical discriminant functions. The first function is $59.6 \%$, and the contribution of the second is $40.4 \%$. (as shown in Table 4)

Table 4. Eigenvalues

\begin{tabular}{|l|l|l|l|l|}
\hline Function & Eigenvalues & \% of Variance & Cumulative \% & Canonical Correlation \\
\hline 1 & $61.525^{\mathrm{a}}$ & 59.6 & 59.6 & .992 \\
\hline 2 & $41.649^{\mathrm{a}}$ & 40.4 & 100 & .988 \\
\hline a. First 2 canonical discriminant functions were used in the analysis.
\end{tabular}

The 2 discriminant equations, which are composed of 18 environmental factor variables. We re-cluster 21 enterprises, and enterprises will $100 \%$ be divided into its original class. Therefor, 2 discriminant equations calculated by SPSS have a strong representative, and it is not difficult to find (as shown in Table 5):

Table 5. Standardized Canonical Discriminant Function Coefficients

\begin{tabular}{|l|r|r|}
\hline & \multicolumn{2}{|c|}{ Function } \\
\hline & 1 & \multicolumn{1}{|c|}{2} \\
\hline Administrative office efficiency & 7.160 & 16.284 \\
Entrepreneur Award policy & 1.659 & -.944 \\
policy consummation degree & -1.770 & .542 \\
diversification of investment & 5.235 & .557 \\
policy orientation & -7.033 & -8.988 \\
risk investment development & 1.571 & -2.444 \\
guarantee system & 4.112 & 12.754 \\
market size & -.475 & -1.034 \\
market competition rate & 2.114 & 2.356 \\
market concentration rate & -9.581 & -3.781 \\
number of universities & -1.324 & -2.669 \\
R\&D funds & 6.284 & 16.864 \\
conversion rate & -9.900 & -14.216 \\
operating status & -2.250 & -6.254 \\
concentration rate & 3.279 & 8.221 \\
degree of industrial linkage & -6.138 & -15.619 \\
talent incentive measures & 6.577 & 11.430 \\
degree of perfection of the talent & 6.405 & 13.725 \\
\hline
\end{tabular}

(1) The enterprises in the stage of development are more concerned with the development of the enterprise itself related to financing, marketing, talent, science and technology environment, while in government policy, the enterprise think that administrative office efficiency influent its enterprise development greatly.

(2) The enterprises in the stage of creation believe that the main factors are policy consummation degree, entrepreneur award policy, risk investment development, market size, the number of universities and market competition rate. The enterprises pay less attention to the talent environment factors. Study shows that the enterprises 
of creation stage pay more attention to government policy for the long-term development of enterprise, and focus on marketing and science and technology environment.

(3) The enterprises in the stage of seed think that the main factors are degree of industrial linka, policy orientation, conversion rate, operating status, etc. Study shows that the enterprises in the seed stage pay more attention for government policy environment, financing environment and science and technology environment.

\section{Conclusion}

After a survey of 21 enterprises we can draw the conclusion on the science and technology enterprises of college students in different stages of the life cycle:

(1) The enterprise of students' science and technology in the development period pay more attention to the talent environment and technology environment. For the financing environment, enterprises hope to find multi-financing channels. For the government policy environment, enterprises pay more attention to governments' office efficiency. This reflects that, college students in the period of development have recognized their operating characteristics, and care more about how to continuously improve the enterprise's own management ability ( pay attention to talent, the market and multi-financing channels ) to seek the development of enterprises.

(2) The enterprise of students' science and technology in the creation period, compared with the other 2 types of enterprises, hope to get more policy support from the government. This reflects enterprises in creation stage have usually not found really suitable road. Therefore, they put their hopes in the development of a favorable external environment for enterprises.

(3) College students' science and technology enterprises in seed stage are concerned about financing environment especially the traditional financing channels and the environment of science and technology. This fundamentally reflects that in reality a part of college students' entrepreneurship think they can provide a product or service which have never invited in market, and they ignore the actual demand of consumption market. College students' entrepreneurship exist the characteristics of blindness.

The enterprises in the development pay more attention to the talent market, science and technology, financing, external environment. They do not have too much demand for government policy environment. Creation and seed stage firms focus on policy environment. However in reality, the financing, talent, marketing and science and technology environment all can affect them. Thus, whichever stage the students scientific and technological enterprises in, what external environment need, from the angle of the macro management, all of which can be summarized as: strengthen the government policy support and guidance, provide a favorable external environment support for college students in scientific and technological enterprises in different life cycle.

\section{Acknowledgements}

This paper is supported by Shanghai University of Engineering Science project under Grant 2015sz12.

\section{References}

CHEN Ying-jie. (2013). Influence of the Entrepreneurial on College Students' Main Business Behaviors. Journal of Higher Education Management, (3).

Duan limin. (2012). Influence of Entrepreneurial Environment on Entrepreneurial Intention of Collgege Sudents: Re-examining GEM Model.Technology Economics, 31(10).

Li Xueling. (2010). Support policy perception and countermeasures and suggestions on university technology business. Technology economics, 29 (11).

Yang Huaizhi, zhang Niancheng, Li Cheng. (2010). The research on technology entrepreneurial environment of college students. Company of Shanghai, (3).

Yi Zhaohui, Xia Qinghua. (2008). Foreign business policy review based on Growth perspective of innovative enterprises. Technology based economy, 27 (8).

Yi Zhaohui. (2006). The empirical analysis on the construction of the entrepreneurial support system.Journal of Chongqing University, 29 (9). 